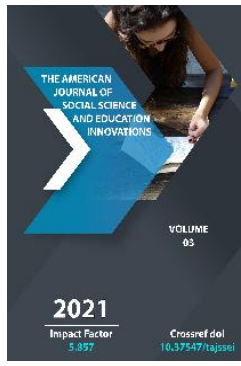

Journal Website: http://theamericanjour nals.com/index.php/taj ssei

Copyright: Original content from this work may be used under the terms of the creative commons attributes 4.0 licence.

\section{Creativity And Pedagogical Activity Of The Academician Of The Art Academy Of Uzbekistan, Holder Of The Order Of Friendship Of Peoples - Janis Salpinkidi (Dedicated To The 75th Anniversary Of The Artist And Teacher)}

Tulanova Dilnoza Juraxanovna

Associate Professor, Tashkent State Pedagogical University Named After Nizami, Tashkent, Uzbekistan

Norboeva Munisa Abdusalom Kizi

Student, Tashkent State Pedagogical University Named After Nizami, Tashkent, Uzbekistan

\title{
ABSTRACT
}

This article examines the possibilities necessary for more effective assimilation of the methods of the visual arts in the preparation of pedagogical personnel in the speciality "Fine Arts" on the example of the work of the artist-teacher Janis Salpinkidi and students of his school.

\section{KEYWORDS}

Academy of Arts, painting, impressionism, art, post-impressionism, realism, education, artist.

\section{INTRODUCTION}

It so happened that the bearers and spokesmen of the leading tendencies that determined the content of the modern artistic process in Uzbekistan were those artists who, back in the 1970s, the years of mature socialist realism, developed the sprouts of creative freedom and internal independence, which rapidly emerged in the 60s. And although there were not very many such artists (including Janis Salpinkidi), the very fact of their existence speaks of new trends in art [14]. The accelerated evolution of fine art in the twentieth century provided by the beginning of the gos developed genre forms of realism with gliding inherent in Uzbek painting and an original version of the impressionistic concept. And also formed its principles of conventionally decorative painting [3-7].

All of the above tendencies characterize the works of Yanis Salpinkidi himself (born 1944) a famous artist of Uzbekistan, Academician and holder of the gold medal of the Academy of Arts of the Republic of Uzbekistan, Knight of the Order of Friendship of Peoples, 
professor of the Department of Fine Arts and Methods of Teaching It at TSPU named after Nizami.

The path of Yanis Panayotovich Salpinkidi as an artist is quite difficult, he began the profession of an artist at a mature age (from 27 years old) without having a workshop. I was forced to teach in an art studio, where I could work, gradually growing into a serious teacher, growing to my students as to my children. A long time ago, at the beginning of Y. Salpinkidi's career, People's Artist of Uzbekistan Nadezhda Kashina, having looked at the works of his young students, noted the professionalism and loyalty of his pedagogical attitude [5-9].

Y. Salpinkidi's pedagogical career began in 1971 at the Faculty of Arts at the TSPI named after Nizami, where he has been working to this day, having worked his way up from a teacher to a university professor. Since 1979 , a member of the Union of Artists of Uzbekistan. For a long creative work, the artist has organized more than 15 personal exhibitions, including several personal exhibitions abroad the Chrysodemis Gallery (1997, Greece), and in the spiritual and educational centre of the city of Athens (2000, Greece). Dylan Hotel in New York City (2011. USA) and others. In parallel with the pedagogical activity in TSPU named after Nizami, pedagogical work was carried out for many years in the experimental art studio "Poisk" (1977) organized by him at the Palace of Aircraft Manufacturers in the city of Tashkent.

Where he raised dozens of professional artists who successfully work in the Republic and abroad. Yu. Ibragimov, D. Iskhakbaev, S. Kurdzhemil, V. Kim, E. Kambina, D. Akhunbabaev, A. Ivanova, V. Khapov - these are the names of his students who continue the pictorial and pedagogical traditions of their mentor.

Speaking about J. Salpinkidi as an artist, it is appropriate to cite an excerpt from the monograph by art critic V.L. Lakovskaya: “... Closely studying nature, he (J. Salpinkidi) creates works of philosophical and metaphorical sound, in which reality is transferred from everyday life to the level of being, and national specifics are filled with universal human problems. ("Irises. Outskirts of Bukhara", "Seeds of Life", "Iranian Cemetery") [10-13].

Since the mid-80s, the artist largely overcomes some speculativeness of his interpretation and comes to the integrity and organicness of the perception of the world ... Many paintings by J. Salpinkidi acquire the quality of spontaneous vitality ("Snag") [1318].

Separately, I would like to say about the gallery of female portraits in the work of $\mathrm{J}$. Salpinkidi. The artist always depicts his models in the interior, surrounded by flowers and fruits, where the central place is given to the magnificent forms of girls and their spiritual world, which are revealed by the artist with the help of surrounding objects and some detachment of the depicted female images. During his long creative period, J. Salpinkidi made many studies, graphic sketches, and as a result - the monumental canvas "Bathers" [1925]. One can involuntarily recall the figurative expression of $\mathrm{K}$. Malevich that "painting grows with forest, stone, trees".

It is also a happy, free youth, an expression of carefree happiness. Picturesque lines intertwine quite naturally, the composition is not imposed by any images from the outside, it is prompted by nature itself and organically reflects the original world of the artist. 
The need to depict a certain whole, which is a world of art, different from the natural world, allows the artist to create works that are perfect in themselves and at the same time open up new facets in art.

And now let us characterize the methods of work of J. Salpinkidi as a teacher. Knowledge, abilities and skills obtained with a wellorganized system of teaching fine arts in the workshop of J. Salpinkidi, and this is work with nature (female and male nude models), the use of various techniques in drawing lessons, and painting, work in mixed media, great open-air practice. Here an excerpt from B. Chukhovich's article suggests itself, which says about the artist's work in nature, that: “... this need (to deepen the artist's contact with nature) was fully shared by the group of Janis Salpinkidi (D. Akhunbabaev, Sh. Baybulatov, Y. Ibragimov, A. Ivanova, E. Kambina, D. Kaipov, V. Kim, S. Kurdzhemil , A. Salpinkidi, O. Zalevskaya, D. Iskhakbaev, D. Khasanov, E. Pilosov, E. Lee, V. Khapov, I. Kulagina, I. Tugaybey). In the works of almost all of its participants, many years of work in the open air are visible. She developed the eyes of painters, adapted their sensitivity to the colour relations characteristic of the Central Asian visual environment ..." [26-31].

All this J. Salpinkidi presents based on the individuality of each student. The result of this is a strong and deep readiness of students in all areas of visual activity, and further competitiveness in creative activity increases, developing into international recognition. So in 2008, a group exhibition "Janis Salpinkidi and his school" was held in China (D. Akhunbabaev, A. Ivanova, E. Kambina, V. Kim, S. Kurdzhemil, O. Zalevskaya, I. Kulagina), in the same year held a personal exhibition of works in pastel technique D. Akhunbabaev in France in Paris (D. Akhunbabaev is a member of the society of pastel masters). Elena
Kambina was invited to Greece in 2010, and then to China with her creative works (installations and video art), in 2011 an exhibition of D. Khapov's works was held in Tachegalleri (New York).

\section{CONCLUSION}

In addition, Y. Salpinkidi, along with in-depth practical work, simultaneously conducts theoretical conversations.

Here we can say that the author of this article, precisely during these conversations on art history, received his most valuable knowledge of the history and theory of fine arts. As an art theorist, Janis Salpinkidi has been keeping extensive diaries for many years, the fundamental significance of which in the future will become a great educational tool both for young generations and for professional artists and art critics. The study by the author of the work methodology of J. Salpinkidi was an attempt to find and improve methods of teaching fine arts in the system of training future teachers of fine arts, which allows developing knowledge, skills and abilities in drawing, painting and other special disciplines, forming interdisciplinary connections between areas of fine arts, activating a creative ability that increases motivation for self-study.

\section{REFERENCES}

1. Туланова Д. (2008). Творчество Я.Салпинкиди. Знаки Времени (Культурные контексты современного искусства Узбекистана: наследие и постмодернизм) Издательство журнала «San'at». Ташкент.

2. Ахмедова Н. (2008). Современное искусство Узбекистана и вопросы методологии. Знаки Времени 
(Культурные

контексты

современного искусства

Узбекистана: наследие и

постмодернизм). Издательство журнала «San'at». Ташкент.

3. Авазбоев, А., \& Хожикаримова, Г. (2019). Социально-педагогические основы формирования креативности учащихся. Вестник науки, 5(6), 150153.

4. Хасанов, А. А., \& Ўроқова, Ш. Б. Қ. (2021). Цифровизация образования на современном этапе развития информатизированного общества. Scientific progress, 2(1), 300-308.

5. Sobitovich, B. S., Ahmedovich, M. N., Erpolatovich, T. N., Khotamovna, G. N., \& Jurakhanovna, T. D. (2020). Principles of using scientific discoveries in modernization of the art education system. Journal of Critical Reviews, 7(11), 2020.

6. Xalilov, R. (2021). Important factors for teaching students to work on landscape composition. Збірник наукових праць $\Lambda$ ОГО https://doi.org/10.36074/logos-

30.04.2021.v2.10.

7. Абдирасилов, С. (2021). Изобразительное искусство узбекистана в патриотическом и эстетическом воспитании школьников. Збірник наукових праць $\Lambda$ 'ОГО

8. Xalimov, M., \& Farxodova, Z. (2021). Developing students creative abilities by making the problem-solving situation in drawing subject. Збірник наукових праць $\Lambda^{\prime} О Г О \Sigma$.

9. Абдусаломходжаев, Н. (2021). Исторические личности в творчестве малика набиева. Збірник наукових праць $\Lambda$ 'ОГО
10. Авазбаев, А., Джураев, Ю., \& Турсунходжаева, $3 . \quad$ (2021). Texnologik ta'lim jarayonini kreditmodul tizimi asosida tashkil etish shart-sharoitlari. Общество и инновации, 2(4/S), 171-176.

11. Ahmedov, M. U., \& Xolmatova, F. (2021). Teaching students to draw elements of patterns in wood carving circles. Збірник наукових праць

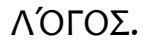

12. Muratov, H. (2021). The importance of organization and management independent education in the learning process. Збірник наукових праць $\Lambda$ 'ОГОг.

13. Alimovich, N. E. (2021). Determination Of General Positions For The Solution Of Geometric Tasks. International Journal of Progressive Sciences and Technologies, 25(2), 237-241.

14. Юлдашева, Н. (2021). Бўлажак тасвирий санъат ўқитувчиларида бадиий-эстетик компетентликни шакллантириш. Збірник наукових праць $\Lambda$ ОГО

15. Назирбекова, Ш. (2021). Тасвирий санъатда рангларнинг тутган ўрни. Збірник наукових праць $\wedge^{\prime} О Г О \Sigma$.

16. Усмонов, Б. Ш., Дадабоева, Д. И., \& Валиева, 3. Т. (2021). NХ-это интегрированное решение для проектирования продуктов, разработка и производство. Scientific progress, 2(1), 825-834.

17. Мансуров, Н. А., \& Собиров, А. Т. (2021). Процесспрофессионального обучения-научная отрасль профессиональной педагогики. Scientific progress, 1(6), 317-324.

18. Xalilov, R.. (2021). Роль карандашного рисунка в будущей профориентации учителей изобразительного искусства. Общество и инновации, 
2(4/S),

585-590.

https://doi.org/10.47689/2181-1415-vol2iss4/S-pp585-590

19. Хасанова, М. (2021). Олий педагогик таълимда “Композиция” фани мазмунини такомиллаштиришда тарихий манбалардан фойдаланиш. Общество и инновации, 2(5/S), 112118.

20. 19.Талипов , Н., \& Талипов , Н. (2021). Проблема исторического жанра в изобразительном искусстве: взгляд на творческую школу художника Малика Набиева. Общество и инновации, 2(4/S), 607-613. https://doi.org/10.47689/2181-1415-vol2iss4/S-pp607-613.

21. Maxkamova, S. B. (2021). Bollajak tasviriy san'at o 'qituvchilarini tasviriy san'atda manzara janridagi asarlarini badiiy tahlil qilishga tayyorlash masalalari. Scientific progress, 2(2), 480-487.

22. Abdurashidxonova, M., \& Rasulov, $M$. (2021). Tashkent school of woodcarving and representatives of Uzbek folk applied art. Society and innovation, 2(5/S), 130-137. https://doi.org/10.47689/2181-1415-vol2iss5/S-pp130-137.

23. Джаббаров, Р. (2021). Sharq uyg 'onish davri yetuk san'atkori buyuk miniatyurachi musavvir Kamoliddin Behzod ijodi ta'sirida yuzaga kelgan o 'ziga xos yo 'nalish. Общество и инновации, 2(5/S), 59-67. https://doi.org/10.47689/2181-1415-vol2iss5/S-pp59-67.

24. Xolmuratovich, M. X., \& Ravshanovich, J. R. (2020). Amaliy va badiiy bezak san'ati. UO'K, 76, 075.

25. Eraliyevich, S. H. (2021). Shaping Students' Spiritual Worldviews Through Fine Arts. The American
Journal of Social Science and Education Innovations, 3(05), 79-86.

26. Namazovna, S. D. (2021). Harmony of Art In Architecture Of Uzbekistan. The American Journal of Social Science and Education Innovations, 3(05), 87-94. https://doi.org/10.37547/tajssei/Volume 03Issue05-16.

27. Jabbarov, R., \& Rasulov, M. (2021). Further formation of students' creative abilities by drawing landscapes in painting. Збірник наукових праць $\Lambda$ ОГО https://doi.org/10.36074/logos-

30.04.2021.v2.09.

28. Nurtaev, U. (2021). Pedagogical issues in ensuring continuous and intermittent state of the field of fine arts in the system of art education. Academicia: an international multidisciplinary research journal, 11(1), 1813-1821.

29. Tulanova, D. (2021). Imaginary line in landscape painting of Uzbekistan. Academicia: an international multidisciplinary research journal, 11(2), 773-778.

30. Gulomova, N. Kh., \& Tulanova, D. Zh. (2017). Using the laws of perspective in teaching fine arts: Materials of scientific and practical. conf. Kakand State Pedagogical Institute (Republic of ilmiy amaliy conference maқolalari teplami. Kukon Davlat pedagogy of the institute).

31. Valiev, A. N., Tulanova, D. Zh., \& Gulomova, N. Kh. (2018). Modern pedagogical and innovative teaching technologies in drawing lessons. Young Scientist, (3), 183-184. 